part in public life has to be set against the imperative demand of the public interest for the maintenance of political impartiality in the Civil Service and for confidence in that impartiality. In other words, it is an essential part of the structure of government in Britain that the Civil Service should not only be impartial but also be seen to be impartial.

The Whitley Committee suggested that between the two classes proposed by the Masterman Committee an intermediate class should be created, and the Government has agreed that this could be done without detriment to the interests of the State or the reputation of the Civil Service for political impartiality. The problem is where to draw the line, and the members of the Whitley Committee are themselves unable to reach agreement. The Government proposes to draw the line so as to include the five groups which both sides of the Committee proposed to include, but excluding junior executive officers and analogous grades, and to bar canvassing to Civil servants restricted in their political activities while allowing it by permission only to those in the intermediate group. The decision, which will give substantial political freedom to a further two hundred thousand Civil servants, appears to be reasonably circumspect, while experience demonstrates that the increased freedom will be used with good sense and discretion. Some 62 per cent of the Civil Service is now completely free of restrictions, and only 16 per cent is barred from participation in national political activities ; and to many of those who seek it, permission to participate in local government may be given.

\section{Standard Solutions of Phosphorus-32}

IT has been found by the Isotope Division, Atomic Energy Research Establishment, Harwell, that phosphorus-metabolizing moulds grow readily in solutions containing phosphorus-32 used as radioactive standards and may cause losses of specific activity in the solution of up to 50 per cent in one week. To inhibit their growth, an addition of 1 per cent formaldehyde is therefore made to such solutions before dispensing and measurement. All solutions thus treated are clearly marked and carry a poison label.

\section{Congress of the Universities of the British Com- monwealth}

THE Seventh Quinquennial Congress of Universities of the Commonwealth will be hold in Cambridge during July 13-17 under the presidency of Marsha.l of the Royal Air Force Lord Tedder, chancellor of the University of Cambridge. Practically every university and university college in the British Commonwealth will be represented by a delegation of teaching and executive officers led by its vicechancellor or principal, making a total of more than four hundred persons, and in addition there will be observers from many learned bodies and a party of ten university presidents nominated by the Association of American Universities. The present Congress is the seventh of the series organized (except for interruptions caused by the two wars) at five-yearly intervals since 1912 by the Association of Universities of the British Commonwealth (formerly the Universities Bureau of the British Empire), the previous meeting having taken place at Oxford in 1948. The chairman of the organizing committee is Sir Philip Morris, vice-chancellor of the University of Bristol and chairman of the Association. The Congress pro- vides an opportunity for the free exchange of views on matters of current importance to the universities of the British Commonwealth, and the following subjects will be discussed at the sessions: government and universities, administration and academic duties, academic mobility in the Commonwealth, higher technological education, and admission and selection of students. A general symposium will also be held on the question: What subject or subjects: to-day are best fitted to fulfil the role played previously in the university curriculum by the classies? By invitation of Sir James Duff, warden of the Durham Colleges in the University of Durham, there will be a meeting of vice-chancellors, presidents and principals of member universities of the Association of Universities of the British Commonwealth at St. Mary's College, Durham, during the week beginning July 6 . This conference will be devoted to private discussion of inter-university relationships and problems of administrative and educational policy common to the various universities of the Commonwealth. Both the above meetings will be private; but further information can be obtained from the Association of Universities of the British Commonwealth, 5 Gordon Square, London, W.C.1.

\section{University of Birmingham}

THE following have been appointed lecturers in the University of Birmingham: Dr. G. W. Greenlees (physics), R. W. Murray (zoology), Dr. W. T. PellWalpole and S. G. Glover (metallurgy) and P. S. Gelling (ancient history and archæology). The title of reader in systematic bacteriology has been conferred on Dr. K. A. Bisset, lecturer in bacteriology in the University.

The University Department of Engineering Production has received a further gift of $£ 57,400$ (under seven-year covenant) from Joseph Lucas and Co., Ltd., the firm which originally endowed the Department, and it is intended that this sum be used for the establishment of a centre for continued studies in engineering production and management. The University has acquired a house at 16 Norfolk Road which is being altered and refurnished and which will shortly be opened as the University of Birmingham Institute for Engineering Production. The aim of the Institute, which will be directed by Prof. T. U. Matthew, Lucas professor of engineering production, is to develop a series of short residential courses in engineering production and management subjects for executives in responsible posts in manufacturing industries. The work of the Institute will be reviewed and liaison with industry maintained through an advisory board, on which a number of industrial leaders will sit with the vice-chancellor and members of the Faculty of Science. It is hoped that the Institute will be opened on July 16 with a fortnight's course on "The Application of Work Study".

\section{University of Leeds: Appointments}

THE following appointments have been mado in the University of Leeds: Prof. T. L. Bywater, at present Strathcona Fordyce professor of agriculture in the University of Aberdeen, to be professor of agriculture and head of the Department of Agriculture; Prof. R. F. E. W. Peel, professor of geography in the University, to be head of the Department of Geography in succession to Prof. A. V. Williamson (see Nature, June 6, p. 1002). The title and status of reader have been conferred on the following members of the University: Dr. A. D. 